\title{
Bariery i możliwości. O haiku na gruncie polskim
}

\author{
Marta Stusek
}

\section{Bariery}

Haiku, gatunek miniatury wywodzący się z poezji starojapońskiej, stał się synonimem krótkiego wiersza, często traktowanego niepoważnie. W powszechnym odbiorze często mylony jest $z$ aforyzmem, fraszką, nieskomplikowaną poetycką zabawą. Do takiego postrzegania przyczyniają się niekiedy także publikacje opatrzone nazwą gatunkową. W mojej refleksji chciałabym zwrócić uwagę nie tyle na formalny, językowy aspekt przekładu dalekowschodniej małej formy na język polski, ile na transpozycję kulturową i jej zasadność. Analizowane przykłady polskiego haiku stanowią twórcze przekształcenia gatunku, pozwalające na wytworzenie nowych jakości artystycznych.

Mimo licznych wątpliwości związanych $\mathrm{z}$ omawianą formą wiersza, o japońskim gatunku i jego polskich realizacjach napisano wiele artykułów, a niedawno (2016) ukazała się obszerna monografia Beaty Śniecikowskiej Haiku po polsku. Genologia w perspektywie transkulturowej. W swojej książce Miniatura poetycka Piotr Michałowski jednoznacznie wypowiada się na temat form mających imitować haiku: 
wienia poetyki cytowanej poetyce realizowanej. Jest natomiast programowe sięganie do źródła, abstrahujące od doświadczeń poprzedników. Tu forma nie stanowi problemu, ale tylko zadanie. Jest aktem wiary, a nie tematem do dyskusji. Następuje też rezygnacja autora z tego co „własne” i czego tak stanowczo bronił autor Haiku-images. „Haikuiści” po prostu uprawiają [wyróżnienie autora - M.S.] gatunek, nie dostrzegając konfliktu kultur i problemu obcości modelu poezji orientalnej. Ich kompozycje są w pewnym sensie anonimowym powielaniem typowych motywów, upodabniając się do przekładów z japońskich mistrzów. Tak jak u początków gatunku, królują schemat i „szkoła”. A zatem - akademizm i klasycyzm ${ }^{1}$.

Badacz w swojej diagnozie wskazuje na kilka istotnych kwestii, przede wszystkim na powielanie wzorców i ignorowanie kulturowych różnic. Michałowski przywołuje wydany już po śmierci autora tomik Stanisława Grochowiaka Haiku-images (1978), w którym poeta wyraźnie inspirował się anglo-amerykańskim imagizmem² - nurtem wykorzystującym motywy i sposób poetyckiego obrazowania zaczerpnięty z japońskiego haiku. Reguły japońskiego gatunku modyfikowane były na wiele sposobów, natomiast klasyczny wzorzec opiera się na kilku zasadach: nieeksponowaniu osobistych przeżyć autora, oszczędnym użyciu środków stylistycznych (niekiedy wskazuje się na niedopuszczalność metafory), delikatnym zabarwieniu smutkiem (kategoria sabi) i łagodnym humorze, nakładaniu się obrazów w wierszu, sygnalizowaniu pory roku (kigo). Haiku wywodzi się z inicjalnej strofy dłuższej pieśni wiązanej (haikai no-renga), dlatego już z jego genezy wynika pewne niedopowiedzenie, otwartość, nastawienie na odbiorcę, swoista przezroczystość. Sam formalny kształt haiku w językach europejskich 17 sylab w trzech wersach (5-7-5) - jest wynikiem dostosowania zapisu w języku japońskim na potrzeby innych alfabetów. Nie wszystkie aspekty gatunku są łatwo (lub w ogóle) przekładalne. Istotną rolę w klasycznym haiku odgrywa słowo/sylaba ucinająca kireji sprzyjająca jukstapozycyjnemu nakładaniu się obrazów w wierszu. W języku polskim zabieg ten poeci uzyskują (lub nie uzyskują wcale) za pomocą innych środków, najczęściej po prostu „zderzając" ze sobą dwa obrazy - pierwszy, przedstawiony w początkowych dwóch wersach i kolejny, mieszczący się w ostatnim wersie - lub odwrotnie - jeden obraz przedstawiony w pierwszym wersie i kolejny w dwóch następnych; czasem wykorzystywany jest myślnik. Dzieje się tak przede wszystkim w tłumaczeniach utworów japońskich mistrzów:

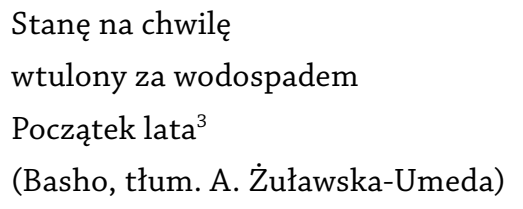

Kwitnący rzepak -

na zachodzie krąg słońca,

na wschodzie księżyc ${ }^{4}$.

(Buson, tłum. R. Krynicki)

\footnotetext{
${ }^{1}$ P. Michałowski, Haiku, [w:] tegoż, Miniatura poetycka, Szczecin 1999, s. 106-107.

2 Zob. L. Engelking, A. Szuba, Obraz i wir. Antologia anglo-amerykańskiego imagizmu, Warszawa 2016.

${ }^{3}$ Be haiku, przeł. A. Żuławska-Umeda, oprac. B. Jewiarz, Warszawa 2017, brak numeracji stron.

${ }^{4}$ R. Krynicki, Haiku mistrzów, [w:] tegoż, Haiku. Haiku mistrzów, Kraków 2014, s. 67.
} 
Wszelkie odczytania i analizy haiku powinny być oparte na świadomości jego konwencji, łączących się nierozerwalnie z japońskimi kategoriami estetycznymi. Przekład (nie tylko językowy) dalekowschodniej miniatury to przeszczepianie kawałka jednej kultury na grunt innej, co Kazuo Sato ujmuje w zgrabnej formule: Czy można przesadzić kwiat rzepaku? ${ }^{5}$. Wyjątkowo mocno zarysowuje się w tym przypadku zaplecze gatunku, rozumianego jako zespół subkodów kultury. Roma Sendyka, wskazując na „kulturowe czynniki mające swój udział w życiu gatunków”, pisze: „granice między gatunkami stały się znowu interesujące, lecz nie jako miejsce rygorystycznego rozdzielenia - lecz jako przestrzeń dynamicznych zderzeń, łączenia, rozmycia, krzyżowania się różnych właściwości”. Właśnie wskazywane przez Sendykę zderzenia są szczególnie interesujące w kontekście adaptacji japońskiej małej formy na grunt polski. Wiele światła na problem w badaniu (polskiego) haiku rzucają przedstawione przez Beatę Śniecikowską uwagi dotyczące metodologii:

\begin{abstract}
Wielorakość zbliżeń do haiku niezmiernie utrudnia decyzje metodologiczne. Niemożliwe okazuje się znalezienie jednego teoretycznego pryzmatu, który pozwoliłby na badawczy ogląd wszystkich wymienionych grup tekstów. Uznaję, że w analizach miniatur bardzo bliskich wyznacznikom wschodniej miniatury warto pokusić się o traktowanie haiku jako inwariantnego zespołu cech. W tym wypadku sprawdzić się może typologiczne rozumienie gatunku. Jak badać utwory - nierzadko znakomite artystycznie - które tylko ocierają się (i to z różnych stron) o haikową estetykę? Co wreszcie z wierszami paratekstualnie, z nie zawsze oczywistych przyczyn, sygnalizującymi związki z japońskimi 17-zgłoskowcami? W takich wypadkach decyduję się na prototypowe modelowanie gatunku? .
\end{abstract}

Zwracam tutaj uwagę na jeszcze jedną rzecz - Śniecikowska pisze o utworach „bardzo bliskich wyznacznikom wschodniej miniatury", a zatem i w tej kwestii może pojawić się wątpliwość, które utwory właśnie za takie uznamy. Należy pamiętać, że niezwykle istotnym kontekstem dla haiku są dalekowschodnie systemy religijne i filozoficzne: buddyzm zen, szintoizm i taoizm. Tymczasem powszechną praktyką w polskich (i nie tylko) realizacjach jest ukazywanie treści związanych $\mathrm{z}$ religią chrześcijańską. Zjawisko to związane jest $\mathrm{z}$ implikowaniem lokalnego kolorytu na grunt obcej formy, które polegałoby tu na zastępowaniu mniej znanego w danej kulturze systemu religijnego systemem powszechnym, znanym. Piotr Michałowski metodę przeszczepiania swojskości w obcą formę nazywa, korzystając z rozpoznań Erazma Kuźmy, inwazyjną ${ }^{8}$.

Należy zatem zastanowić się, czy haiku, przekraczające tematycznie i formalnie wymagania prototypowego gatunku, nie jest nieporozumieniem. Również monografistka polskiej postaci dalekowschodniej miniatury pyta o haiku chrześcijańskie i wskazuje na utwory wyraźnie odnoszące się do religii, jak i te realizujące „zen po polsku”:

\footnotetext{
${ }^{5}$ Zob. K. Sato, Czy można przesadzić kwiat rzepaku? (japońskie haiku i ruch haiku na zachodzie), przeł. A. Szuba, „Literatura na Świecie” 1991, nr 1.

${ }^{6}$ R. Sendyka, W stronę kulturowej teorii gatunku, [w:] Kulturowa teoria literatury. Główne pojęcia i problemy, red. M.P. Markowski, R. Nycz, Kraków 2006, s. 277.

${ }^{7}$ B. Śniecikowska, Haiku po polsku. Genologia w perspektywie transkulturowej, Toruń 2016, s. 18.

${ }^{8}$ P. Michałowski, Polskie imitacje haiku, „Teksty Drugie: teoria literatury, krytyka, interpretacja” 1995, nr 2, s. 47.
} 
Polskie „zenistyczne” haiku to utwory dalekie od moralizatorstwa, niewyrażające żadnej misji, po prostu afirmacyjne. Z typową dla nich monumentalnością, skupieniem na przeżywanej chwili silnie kontrastują teksty swoiście „uduchowione”, odsyłające do niesprecyzowanych przestrzeni metafizycznych [wyróżnienie moje - M.S.]. Nie sposób jednoznacznie ustalić, czy wiersze te odwołują się do chrześcijaństwa, czy też innych religii bądź ścieżek duchowych. To utwory konotujące swoiście wzniosłe sensy, odsyłające do nieogarnionych przestrzeni, subtelne aluzyjnie religijnie ${ }^{9}$.

Przykładem ilustrującym to zagadnienie jest haiku księdza Janusza Stanisława Pasierba. W tomiku Morze, obłok i kamień (1992) poeta wykorzystuje trzy tytułowe elementy przyrody poza-ludzkiej/pozaludzkiej do przekazania treści egzystencjalnych, w znacznej mierze o religijnym zabarwieniu:

\author{
obłok to zapowiedź \\ kamień odpowiedź \\ morze spełnienie \\ obłok Zwiastowanie \\ kamień Wielkanoc \\ morze spełnienie ${ }^{10}$ \\ kto rzuca \\ obłoki kamienie kości \\ kto gra ziemią morzem nami? \\ obłok na uwięzi \\ ukamienowane morze \\ kto zwyciężył? ${ }^{11}$
}

Pasierb nie przestrzega formalnych rygorów haikowego układu sylabicznego. Pozostaje wierny formule trzech ascetycznych wersów, jednak liczba sylab w poszczególnych utworach jest różna, pojawiają się wersy mniej i bardziej rozbudowane. Interesujące okazuje się rozwiązanie kwestii obrazowania - autor Butelki lejdejskiej korzysta cały czas z jednego obrazu złożonego z przywołanych w tytule elementów przyrody. Korzystając z minimalistycznych środków wyrazu, Pasierb za każdym razem rzuca na nie inne światło. Tworząc przed czytelnikiem prosty rysunek morskiego pejzażu, każdorazowo inaczej programuje odbiór tego wycinka rzeczywistości, a jego obserwacja prowadzi do rozważań natury kosmologicznej. Oprócz tropów biblijnych w haiku pojawia się także teologiczna refleksja, zostaje postawione pytanie o Tego, „Kto gra ziemią morzem nami?”. Janusz Stanisław Pasierb nie tworzy jednak „katolickiego haiku", lecz wykorzystuje minimalizm japońskiej konwencji do wyrażenia treści religijnych (część utworów nawiązuje do chrześcijaństwa poprzez Zwiastowanie, Wielkanoc czy ukamienowanie) lub metafizycznych, niekoniecznie związanych z dogmatami konkretnej religii.

\footnotetext{
${ }^{9}$ B. Śniecikowska, Haiku po polsku..., s. 460.

${ }^{10}$ J.S. Pasierb, Morze, obłok i kamień, cyt. za: Antologia polskiego haiku, red. E. Tomaszewska, Warszawa 2001, s. 95.

${ }^{11}$ Tamże, s. 96-97.
} 


\section{Możliwości}

Przekroczenia gatunku, autorskie formy miniatur, które wykorzystują wiele elementów klasycznej konwencji, jednocześnie modyfikując je w celu uzyskania nowych jakości, są niejednokrotnie znacznie ciekawszymi projektami niż te dążące do wierności japońskiemu oryginałowi. Na potencjał haiku już ponad dwadzieścia lat temu wskazywał Czesław Miłosz:

Poeci haiku trzymają się na uboczu i nie są częścią krajobrazu współczesnej poezji. W toczonych przez nich dyskusjach pada pytanie, na ile powinny obowiązywać reguły właściwe temu gatunkowi. W rezultacie zarzucili sylabiczną budowę i zastosowali wiersz tzw. wolny w trzech linijkach, dbając o jak największą zwięzłość. Dla niektórych nawet trzy linijki to za dużo i wprowadzili haiku jednoliniowe. Inne pytanie dotyczy przeżycia, które znajduje wyraz: religijne czy estetyczne? Znaczna część autorów pod wpływem buddyzmu Zen szuka religijnego oświecenia, inni wprowadzają chwile innych doświadczeń, również erotycznych. W każdym razie z różnorodności tematów można wyciągnąć wniosek, że powstaje coś nowego, właściwego cywilizacji przemysłowo-technicznej, w której zresztą uwaga zwrócona ku przyrodzie ma szczególne (ożywcze) znaczenie ${ }^{12}$.

Uwagi Miłosza można odnieść do współczesności. O ile wielokrotnie wskazywano na możliwości haiku w zakresie „zdobycia nowego spojrzenia” ${ }^{13}$, o tyle do tej pory nie analizowano owego potencjału pod kątem nowych metodologii i praktyk interpretacyjnych, jak np. ekopoety$\mathbf{k a}^{14}$. Nieeksponowanie własnych przeżyć w wierszu i akcentowanie równoważności każdego elementu przyrody odsuwa antropocentryczną wizję świata na rzecz bardziej równościowej, podkreślającej współistnienie wszystkich gatunków. Przekonanie o jedności z przyrodą pozaludzką zarysowuje się chociażby w utworze Jadwigi Stańczakowej:

Błękit przestrzeni

zieleń traw pod stopami

kosmos jest domem ${ }^{15}$

Haiku autorki Depresji i wróżb cechuje różnorodność: wśród utworów sytuujących się blisko klasycznego wzorca można znaleźć także takie, w których autorka wykorzystuje konwencję haiku do ukazania doświadczenia niewidzenia, np.

Wianek z modrzewia

ślepa kładzie na grobie

i serce widzi ${ }^{16}$

${ }^{12}$ C. Miłosz, Wprowadzenie, w: tegoż, Haiku, Kraków 1992, s. 16-17.

${ }^{13}$ Zob. D.T. Suzuki, Satori, czyli zdobycie nowego punktu widzenia, [w:] tegoż, Wprowadzenie do buddyzmu zen, przeł.

M. i A. Grabowscy, Poznań 2004

${ }^{14}$ Zob. J. Fiedorczuk, G. Beltrán, Ekopoetyka. Ekologiczna obrona poezji, Warszawa 2015.

${ }^{15} \mathrm{~J}$. Stańczakowa, Haiku, Wrocław 2015, s. 10.

${ }^{16}$ Tamże, s. 28. 
W dłoni biedronka

w kropeczki brajla

więc ją wyczuwam ${ }^{17}$

Haiku Stańczakowej to z jednej strony utwory naśladujące japońskich mistrzów, z drugiej świadectwo własnego sposobu patrzenia na świat. Słowo „patrzenie” jest tutaj istotne. Dla poetki niewidzenie to część tożsamości. Nie jest brakiem, jest innym sposobem doświadczania i widzenia świata, czego twórczym wyrazem może być właśnie forma haiku.

W 2014 roku Ryszard Krynicki wydał Haiku. Haiku mistrzów. Tomik podzielono na trzy części: w pierwszej zebrane zostały miniatury nazwane Prawie haiku, w drugiej niepublikowane wcześniej Haiku z minionej zimy - utwory formalnie, poprzez tematykę oraz układ sylab i wersów zbliżone do klasycznego wzorca, trzecia zaś, Haiku mistrzów, gromadzi przekłady utworów japońskich mistrzów: Basho, Busona, Issy i Shikiego (Krynicki nie tłumaczył z języka oryginału - korzystał w przekładów angielskich i niemieckich). Haiku autora Organizmu zbiorowego można określić jako punkt dojścia w jego poetyckiej drodze. Wyraźna inspiracja japońskim gatunkiem przejawia się zarówno w minimalizmie formy, jak i tematyce utworów poprzedzających autorskie wykorzystanie konwencji, czyli tekstów, które poeta nazwał prawie haiku:

Prawie haiku

$$
\begin{aligned}
& \text { nisko kołuje kruk niewidzialny } \\
& \text { widzicie go? }
\end{aligned}
$$

Hans Arp

Klinowe pismo kruka na śniegu:

- Ja jeszcze nie wymarłem.

Ty, który to czytasz,

Też $\dot{z}^{18}$

Nadal nie wiem

Mój ukochany Issa napisał ponoć aż trzy tysiące haiku.

Przeczytałem o tym czternaście lat temu

i nadal nie wiem, co mam o tym myśleć ${ }^{19}$.

We „właściwym” haiku Krynickiego, ułożonym w cykl nazwany Haiku z minionej zimy, zarysowuje się egzystencjalna refleksja:

\footnotetext{
${ }^{17}$ Tamże, s. 55.

${ }^{18}$ R. Krynicki, Prawie haiku, [w:] tegoż, Haiku. Haiku mistrzów, s. 21.

${ }^{19}$ R. Krynicki, Nadal nie wiem, [w:] tegoż, Haiku. Haiku mistrzów, s. 22.
} 


\author{
Rusałka pawik?! \\ Kruche piękno w żałobie \\ Stulonych skrzydeł ${ }^{20}$.
}

Uważna obserwacja przyrody prowadzi do szerszych rozważań, przedstawianych w bardziej bezpośredni sposób niż w klasycznym haiku. Krynicki tworzy esencjonalne, filozofujące miniatury, w których rygor japońskiej formy pozwala mu na dużą precyzję słowa. W repertuarze poety pojawiają się również przykłady bardziej inwazyjne, ukazujące lokalny koloryt, mocno związane z polską codziennością:

$$
\begin{aligned}
& \text { Tramwaj, dziewczyna } \\
& \text { żegna się z koleżanką: } \\
& \text { - No to pa, kurwa }{ }^{21} \text { ! }
\end{aligned}
$$

Jako twórca małych form nawiązujących do japońskiego gatunku dał się także poznać Leszek Engelking, tłumacz miniatur poetów języka angielskiego i wierszy imagistycznych. We wcześniejszych miniaturach poeta pozostawał bliższy konwencjonalnemu haiku, późniejsze jego teksty w tomie Komu kibicuja umarli (2013) przepełnione zostają czarnym humorem. Wszystkie trójwersowe wiersze opatrzone są tytułem Haiku. Specyficzne ujęcie tematu śmierci każe widzieć w małych formach Engelkinga makabreski:

Haiku

msza pogrzebowa

nagle $z$ trumny dobiega

dzwonek komórki ${ }^{22}$

Poecie udaje się uzyskać efekt kontrastu pokrewny nakładaniu się obrazów w haiku - Engelking zderza podniosły nastrój (msza pogrzebowa) z groteskowym humorem (dźwięk telefonu dobywający się z trumny). Łączenie tych elementów niejednokrotnie pozwala autorowi Suplementu na uzyskanie ciekawych efektów:

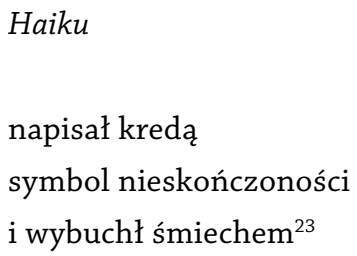

W tym, jak i w innych miniaturowych utworach Engelkinga śmiech zazębia się z powagą groteskowe motywy wprowadzają zarówno nutę komizmu, jak i filozoficzną refleksję o prze-

\footnotetext{
${ }^{20}$ Tegoż, Haiku z minionej zimy, [w:] tegoż, Haiku. Haiku mistrzów, s. 35.

${ }^{21}$ Tamże, s. 42.

${ }^{22}$ L. Engelking, Haiku [msza pogrzebowa...], [w:] tegoż, Komu kibicujq̨ umarli, Poznań 2013, s. 31.

${ }^{23}$ L. Engelking, Haiku [„napisał kredą...”], [w:] tegoż, Komu kibicują umarli, s. 28.
} 
mijaniu. Wykorzystując haikowy ascetyzm formy, poeta ukazał swoisty absurd egzystencji naznaczonej pragnieniem wieczności. Życie okazuje się jednak tak samo nietrwałe jak materiał, którym bohater - nienazwany, zasygnalizowany jedynie osobową formą czasownika - pisze symbol nieskończoności. Ludzkie dążenie do wybicia się ponad śmiertelność kończy się wybuchem śmiechu, człowiek dystansuje się wobec swoich własnych pragnień, zdaje sobie sprawę z gorzkiej prawdy. W tomie Komu kibicujq umarli? śmierć momentami ukazywana jest dosadnie:

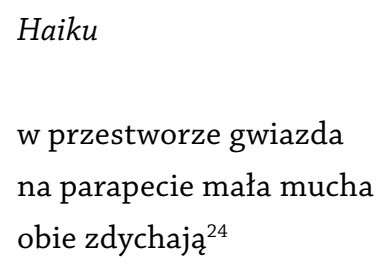

Z kolei innym razem ukazana jest w łagodnej, niemalże impresjonistycznej formie:

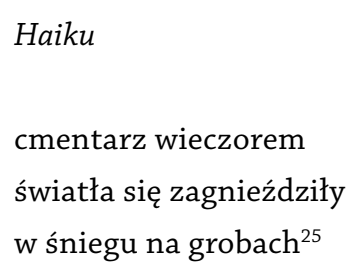

Haiku Engelkinga przywodzi na myśl tradycję tworzenia wierszy śmierci ${ }^{26}$, polski poeta jest jednak w pisaniu o tematach ostatecznych bardziej bezpośredni, usuwa barierę niedosłowności, balansuje na granicy liryzmu i swoistej drastyczności.

Warto także zwrócić uwagę na wizualne aspekty publikowania haiku, jego stronę wydawniczą. Bogata tradycja miniatury i związanych z nią zjawisk pokrewnych, takich jak haiga - połączenie wiersza i grafiki - otwierają szerokie pole możliwości wykorzystania medium drukowanej książki (i nie tylko). Aby przyjrzeć się relacji haiku i sztuk wizualnych nie trzeba sięgać do dzieł starojapońskich - potencjał tkwiący w estetyce związanej z dalekowschodnią małą formą wykorzystywany jest (z mniejszym i większym powodzeniem) także w polskich publikacjach. Przykładem może być Nie-pełna pustka. Haiku wydawnictwa Austeria, w której dopełnieniem wierszy Elżbiety Tabakowskiej są sumi-e autorstwa Lidii Rozmus - monochromatyczne obrazy nawiązujące do kaligrafii.

Ciekawym projektem jest również propozycja wydawnictwa „Blue Bird” - Be haiku to połączenie utworów japońskich mistrzów (w tłumaczeniu Agnieszki Żuławskiej-Umedy) z minimalistycznymi, konceptualnymi grafikami Ryszarda Kajzera. W wyborze wierszy obok polskich przekładów (bezpośrednio z oryginału) wybitnej japonistki i popularyzatorki haiku umieszczono także oryginalny zapis japoński. Nawet dla czytelników nieznających języka, których

\footnotetext{
${ }^{24}$ L. Engelking, Haiku [„,w przestworze gwiazda...”], [w:] tegoż, Komu kibicujq umarli, s. 24.

${ }^{25}$ L. Engelking, Haiku [„cmentarz wieczorem...”], [w:] tegoż, Komu kibicujq umarli, s. 34.

${ }^{26}$ Zob. Japońskie wiersze śmierci, tłum. i wstęp M. Has, Kraków 2004.
} 
zapewne jest większość, zabieg może okazać się trafionym pomysłem, uświadamia bowiem odmienność pierwotnego zapisu wersowego, a co za tym idzie - ukazuje także inną estetykę. Niebagatelne są tutaj także kwestie percepcji wzrokowej, mówiąc najprościej - wiersz inaczej wygląda. Dopełnieniem publikacji jest zamieszczenie na końcu „pustych”, wykropkowanych trzech wersów, stanowiących zachętę dla czytelnika - wolne miejsce na wiersz, jak czytamy we wstępie Beaty Jewiarz: „tatuaż na marginesie świadomości”27.

Wskazując na potencjał japońskiej miniatury, chciałabym także zasygnalizować problem haiku w Internecie. Tak jak zauważa Beata Śniecikowska ${ }^{28}$, twórcy internetowej haigi i haiku w większości nie wykorzystują możliwości, jakie stwarza im sieciowe medium. Rzadko kiedy tego typu propozycje są z nim nierozłącznie związane - projekty najczęściej równie dobrze mogłyby funkcjonować na papierze, w tradycyjnej formie książki ${ }^{29}$. Mimo to należy wskazać, że percepcja haiku i percepcja, jakiej wymaga od użytkowników Internet, mogą zawierać pewne analogie. Sieć i urządzenia mobilne przyzwyczajają czytelnika do szybkiego przeglądu treści, swoistego „chwytania” krótkich tekstowych (i tekstowo-wizualnych) komunikatów, co także przyczynia się do popularności małych form poetyckich. Być może haiku wraz ze swoim minimalizmem i impresyjnością ma szansę na wpisanie się w obecny model obcowania z tekstem.

Należy podkreślić, że wytyczanie zbyt szerokich granic dla orientalnego liryku wiąże się z pewnym niebezpieczeństwem uznania japońskiej miniatury za synonim krótkiego wiersza. Jednakże, jak pokazują analizy poszczególnych przykładów, przekroczenia gatunku potrafią skutkować wartościowymi realizacjami zasady „minimum słów - maksimum treści”. Tendencja do banalizowania haiku w jego recepcji wiąże się także z trywializowaniem znaczenia miniatury poetyckiej w ogóle. Mała forma, choć upodobało ją sobie wielu uznanych poetek i poetów, często pozostaje niedoceniana, traktowana jako dodatek do twórczości właściwej, czyli form dłuższych. Marcin Telicki pisał:

Wielu profesjonalnych czytelników zgadza się, że między utworem operującym minimalną liczbą słów a arcydziełem trudno postawić znak równości. Ignorowanie krótkiej formy poetyckiej jest dość powszechne. [...] potoczny odbiór wiersza krótkiego jako nieskomplikowanego, uproszczonego, pozbawionego stylistycznej różnorodności i nie mającego wartości poznawczych czy artystycznych, jest bezzasadny. Bywa on nawet - paradoksalnie - dużo trudniejszy niż odbiór wiersza „tradycyjnego”. Skąd to odczucie? ${ }^{30}$.

Haiku idealnie wpisuje się w kategorię „wiersza mniejszego” - pozostaje poza mainstreamem, wykorzystuje formalny minimalizm, wywodzi się z innego kręgu kulturowego. Wszystko to sprawia, że kontakt $\mathrm{z}$ japońskim wierszem może skończyć się niezrozumieniem. Niemniej dalekowschodnia miniatura jest w swoim ascetyzmie i przejrzystości formą wyjątkowo

\footnotetext{
${ }^{27}$ B. Jewiarz, Pomiędzy, [w:] Be haiku, oprac. B. Jewiarz, Warszawa 2017, brak numeracji stron.

${ }^{28}$ B. Śniecikowska, Haiku po polsku..., s. 633.

${ }^{29}$ Przywołać można chociażby wybór klasycznych utworów haiku, który funkcjonuje zarówno w wersji cyfrowej, jak i drukowanej: 〈http://www.haiku.art.pl/? ? [dostęp: 30.06.2018].

${ }^{30} \mathrm{M}$. Telicki, Krótkie formy liryczne wobec problemu przedstawiania rzeczywistości, „Przestrzenie Teorii” 2006, nr 6, s. 85-86.
} 
praktyki | Marta Stusek, Bariery i możliwości. O haiku na gruncie polskim

mocno nastawioną na udział odbiorcy. W konsekwencji zarówno obcowanie z klasyką gatunku, wiernym naśladownictwem, jak i interesującą artystycznie wariacją na temat haiku, może okazać się dla czytelniczek i czytelników owocnym doświadczeniem pozwalającym na zmianę świadomości i zyskanie nowego spojrzenia. 


\section{SŁOWA KLUCZOWE:}

\section{H A I K U}

mata forma poetycka

\section{Abstrakt:}

Artykuł stanowi omówienie adaptacji haiku w Polsce. Autorka ukazuje problemy dotyczące recepcji i przekładu japońskiej miniatury oraz wątpliwości w rozumieniu istoty gatunku. W drugiej części pracy wskazane zostają możliwości twórczego wykorzystania haiku w celu osiągnięcia nowych efektów artystycznych. Analizie poddane zostały m.in. utwory Jadwigi Stańczakowej, Ryszarda Krynickiego, Leszka Engelkinga. 
praktyki | Marta Stusek, Bariery i możliwości. O haiku na gruncie polskim

\section{miniatura}

\section{NOTA O AUTORzE:}

Marta Stusek - ur. 1992, doktorantka w Zakładzie Literatury XX Wieku, Teorii Literatury i Sztuki Przekładu na Uniwersytecie im. Adama Mickiewicza w Poznaniu. Zajmuje się literaturą współczesną, w szczególności zagadnieniem małej formy poetyckiej. Interesuje się także powinowactwem sztuk. Publikowała m.in. w „Poznańskich Studiach Polonistycznych”, „Forum Poetyki”, „Pro Arte” oraz w monografiach wieloautorskich. 